\section{Species composition and seasonal variation of butterflies in Dalma Wildlife Sanctuary, Jharkhand, India}

\section{Sushant Kumar Verma}

At \& P.O.- Harharguttu, Near TRF Colony, Jamshedpur, Jharkhand 831002, India

Email: vermasushant2008@gmail.com;

vermasushant2008@rediffmail.com

The Dalma Wildlife Sanctuary is located $10 \mathrm{~km}$ from Jamshedpur in Jharkhand. It extends over $193 \mathrm{~km}^{2}$ in the thick forest of Dalma mountain range, which rises to an elevation of 3,oooft. This wildlife sanctuary is the habitat of many wild animals. Climatic conditions in Dalma are typical of Indian Sal (Shorea robusta) forest. Annual temperature varies from $10^{\circ} \mathrm{C}$ to $42^{\circ} \mathrm{C}$. The hottest months are May and June. The period from November to February is comparatively cool. The maximum rainfall is received during the months of July and August from the South West Monsoon. The natural vegetation comprises of a combination of Sal forest and tropical dry deciduous types.

Information on the butterflies and their seasonal population trends have been recorded for two years and the results are presented in this paper. Classification adopted here is based on Ackery (1989).

\section{Methods}

The butterfly fauna of Dalma Wildlife Sanctuary was surveyed from January 2007 to December 2008. Sampling was conducted at sites dominated by the most representative vegetation type of the region i.e. tropical dry-deciduous forest. To understand the diversity and seasonal variation, transects of 500m length and $10 \mathrm{~m}$ width were laid at three different sites within the sanctuary. All selected sites had similar vegetation comprised mainly of scattered trees of Shorea robusta,

Date of online publication 26 May 2009

ISSN 0974-7907 (online) | 0974-7893 (print)

Editor: Peter Smetacek

\section{Manuscript details:}

Ms \# 02126

Received 27 January 2009

Final received 20 March 2009

Finally accepted 31 April 2009

Citation: Verma, S.K. (2009). Species composition and seasonal variation of butterflies in Dalma Wildlife Sanctuary, Jharkhand, India. Journal of Threatened Taxa 1(5): 295-297.

Copyright: (c) Sushant Kumar Verma 2009. Creative Commons Attribution 3.0 Unported License. JoTT allows unrestricted use of this article in any medium for non-profit purposes, reproduction and distribution by providing adequate credit to the authors and the source of publication.

Acknowledgements: The author is grateful to Dr. A. Alim, Department of Zoology, Jamshedpur Co-operative College, Jamshedpur, for his valuable suggestions. The author expresses his sincere gratitude to Miss Ghazala Sabih (MCA Project Trainee, TISCO) and Sanjay Kumar Mahato (Curator, Tata Steel Zoological Park, Jamshedpur) for their generous help throughout the study period.

\section{OPEN ACCESS |FREE DOWNLOAD (c) (D) (口)}

Buchanania lauzen, Diospyros melanoxylon and Cleistanthus collinus along with bushes of Lantana spp. Ttransects in each of the selected sites were surveyed on foot, one day in every week between 0900hr and $1700 \mathrm{hr}$ for a period of 92 weeks. Species were identified in the field, and where identification was not possible photographs were taken. Collection was restricted only to those specimens that could not be identified with certainty. The trapped butterflies were brought to the laboratory and placed in a killing bottle containing a wad of cotton soaked in ethyl acetate. After relaxing and setting they were identified with the help of field guides (Goodden 1976; Brooks \& Knight 1985; Kunte 2000).

Each year was divided into four seasons. These seasons were: (1) Spring - February and March, (2) Summer - April to June, (3) Rainy season - July to September and (4) Winter October to January. For each year a data matrix was constructed which recorded the species and their abundance in each season.

Seasonal variation in the abundance of butterflies was calculated using the Shannon-Weiner formula $(\mathrm{H})$ as given below:

$\mathrm{N}$

$\mathrm{H}=-\sum \mathrm{Pi} \log \mathrm{Pi}$

$\mathrm{i}=1$

Where $\mathrm{H}=$ species diversity index

$\mathrm{Pi}=$ the proportion of individuals in the $i$ th species

$\mathrm{N}=$ total number of species

$\mathrm{i}=$ species $1,2,3 \ldots \mathrm{N}$

\section{Results}

Altogether 39 species of butterflies belonging to 4 families were recorded. Nymphalidae dominated the list with 20 species, followed by Pieridae (9 species), Lycaenidae (6 species) and Papilionidae (4 species) respectively (Table 1 ).

Fig. 1 shows the values of the index calculated by the Shannon-Weiner equation. Maximum diversity was observed during the last weeks of winter and during spring, while a comparatively low diversity was observed during the rainy season and summer. The number of butterfly species varied with the seasons (Table 1). The maximum number of butterflies was observed during spring and at the height of winter. Species richness showed a reduction at the end of the rainy season (September) and during the warmest part of summer (April to May).

When species richness by family in each season was considered (Fig. 2), Nymphalidae and Lycaenidae attained maximum species richness during the rainy season with a slight decrease during summer. There was only slight seasonal variation in species richness in the case of Pieridae and Papilionidae. Pieridae showed a slight decrease during the rainy season, whereas Papilionidae showed an increase in the value of species richness during summer.

Flowers of Lantana (Verbenaceae) bushes were found to be attractive to a variety of butterflies.

\section{Discussion}

Chandra et al. (2007) reported 147 species of butterflies excluding Hesperiidae from Madhya Pradesh and Chhattisgarh. The present study area covers a much smaller area. All the same, the occurrence of 39 species does not suggest 
Table 1. Butterflies recorded at Dalma Wildlife Sanctuary and their seasonal distribution

\begin{tabular}{|c|c|c|c|c|c|c|c|}
\hline \multirow{2}{*}{$\frac{\text { SNo }}{1 .}$} & \multirow{2}{*}{$\begin{array}{l}\text { Family } \\
\text { Nymphalidae }\end{array}$} & \multirow{2}{*}{$\begin{array}{l}\text { Common Name } \\
\text { Tawny Coster }\end{array}$} & \multirow{2}{*}{$\begin{array}{l}\text { Scientific Name } \\
\text { Acraea violae (Fabricius ) }\end{array}$} & \multicolumn{4}{|c|}{ Seasons Observed } \\
\hline & & & & $\mathrm{Sp}$ & - & $\mathrm{Rn}$ & Wi \\
\hline 2. & & Glassy Tiger & Parantica aglea (Cramer) & $\mathrm{Sp}$ & - & $\mathrm{Rn}$ & - \\
\hline 3. & & Blue Tiger & Tirumala limniace (Cramer) & & $\mathrm{Su}$ & - & - \\
\hline 4. & & Plain Tiger & Danaus (Anosia) chrysippus (Linnaeus.) & $\mathrm{Sp}$ & Su & $\mathrm{Rn}$ & Wi \\
\hline 5. & & Common Crow & Euploea core (Cramer) & $\mathrm{Sp}$ & $\mathrm{Su}$ & $\mathrm{Rn}$ & Wi \\
\hline 6. & & Brown King Crow & Euploea klugii (Moore) & $\mathrm{Sp}$ & - & $\mathrm{Rn}$ & - \\
\hline 7. & & Common Fourring & Ypthima hübneri (Kirby) & & - & - & Wi \\
\hline 8. & & Great Eggfly & Hypolimnas bolina (Linnaeus) & - & Su & - & Wi \\
\hline 9. & & Common Sailer & Neptis hylas (Linnaeus) & $\mathrm{Sp}$ & - & & Wi \\
\hline 10. & & Common Baron & Euthalia aconthea (Cramer) & - & Su & $\mathrm{Rn}$ & - \\
\hline 11. & & Baronet & Symphaedra nais (Forster) & - & Su & $\mathrm{Rn}$ & Wi \\
\hline 12. & & Common Bushbrown & Mycalesis perseus (Fabricius) & & Su & $\mathrm{Rn}$ & - \\
\hline 13. & & Common Castor & Ariadne merione (Cramer) & $\mathrm{Sp}$ & - & $\mathrm{Rn}$ & Wi \\
\hline 14. & & Angled Castor & Ariadne ariadne (Linnaeus) & $\mathrm{Sp}$ & - & - & - \\
\hline 15. & & Common Palmfly & Elymnias hypermnestra (Linnaeus) & - & - & $\mathrm{Rn}$ & \\
\hline 16. & & Common Leopard & Phalanta phalantha (Drury) & $\mathrm{Sp}$ & $\mathrm{Su}$ & $\mathrm{Rn}$ & Wi \\
\hline 17. & & Blue Pansy & Junonia orithya (Linnaeus) & $\mathrm{Sp}$ & - & $\mathrm{Rn}$ & \\
\hline 18. & & Grey Pansy & Junonia atlites (Linnaeus) & $\mathrm{Sp}$ & - & $\mathrm{Rn}$ & \\
\hline 19. & & Lemon Pansy & Junonia lemonias (Linnaeus) & & - & $\mathrm{Rn}$ & Wi \\
\hline 20. & & Peacock Pansy & Junonia almana (Linnaeus) & $\mathrm{Sp}$ & - & & Wi \\
\hline 21. & Papilionidae & Lime Butterfly & Papilio demoleus (Linnaeus) & - & Su & - & Wi \\
\hline 22. & & Common Banded Peacock & Papilio crino (Fabricius) & $\mathrm{Sp}$ & Su & $\mathrm{Rn}$ & - \\
\hline 23. & & Common Mormon & Papilio polytes (Linnaeus) & $\mathrm{Sp}$ & $\mathrm{Su}$ & $\mathrm{Rn}$ & - \\
\hline 24. & & Common Jay & Graphium doson (C. \& R. Felder) & $\mathrm{Sp}$ & Su & & Wi \\
\hline 25. & Pieridae & Common Emigrant & Catopsilia pomona (Fabricius) & $\mathrm{Sp}$ & $\mathrm{Su}$ & $\mathrm{Rn}$ & Wi \\
\hline 26. & & Mottled Emigrant & Catopsilia pyranthe (Linnaeus) & - & Su & - & Wi \\
\hline 27. & & Common Grass Yellow & Eurema hecabe (Linnaeus) & $\mathrm{Sp}$ & $\mathrm{Su}$ & $\mathrm{Rn}$ & Wi \\
\hline 28. & & Small Grass Yellow & Eurema brigitta (Cramer) & $\mathrm{Sp}$ & Su & $\mathrm{Rn}$ & Wi \\
\hline 29 & & Common Gull & Cepora nerissa (Fabricius) & - & - & $\mathrm{Rn}$ & Wi \\
\hline 30. & & Psyche & Leptosia nina (Fabricius) & $\mathrm{Sp}$ & Su & - & Wi \\
\hline 31. & & Common Wanderer & Pareronia valeria (Cramer) & & Su & $\mathrm{Rn}$ & Wi \\
\hline 32 & & Common Albatross & Appias albina (Boisduval) & $\mathrm{Sp}$ & - & - & - \\
\hline 33. & & Common Jezebel & Delias eucharis (Drury) & $\mathrm{Sp}$ & Su & $\mathrm{Rn}$ & Wi \\
\hline 34. & Lycaenidae & Monkey Puzzle & Rathinda amor (Fabricius) & - & - & $\mathrm{Rn}$ & Wi \\
\hline 35. & & Dark Cerulean & Jamides bochus (Stoll) & $\mathrm{Sp}$ & Su & & Wi \\
\hline 36. & & Common Cerulean & Jamides celeno (Cramer) & $\mathrm{Sp}$ & - & & Wi \\
\hline 37. & & Common Pierrot & Castalius rosimon (Fabricius) & $\mathrm{Sp}$ & Su & $\mathrm{Rn}$ & - \\
\hline 38. & & Rounded Pierrot & Tarucus nara (Kollar) & $\mathrm{Sp}$ & $\mathrm{Su}$ & $\mathrm{Rn}$ & Wi \\
\hline 39. & & Common Hedge Blue & Acytolepis puspa (Horsfield) & - & Su & & Wi \\
\hline
\end{tabular}

Sp - Spring; Su - Summer, Rn - Rainy; Wi - Winter

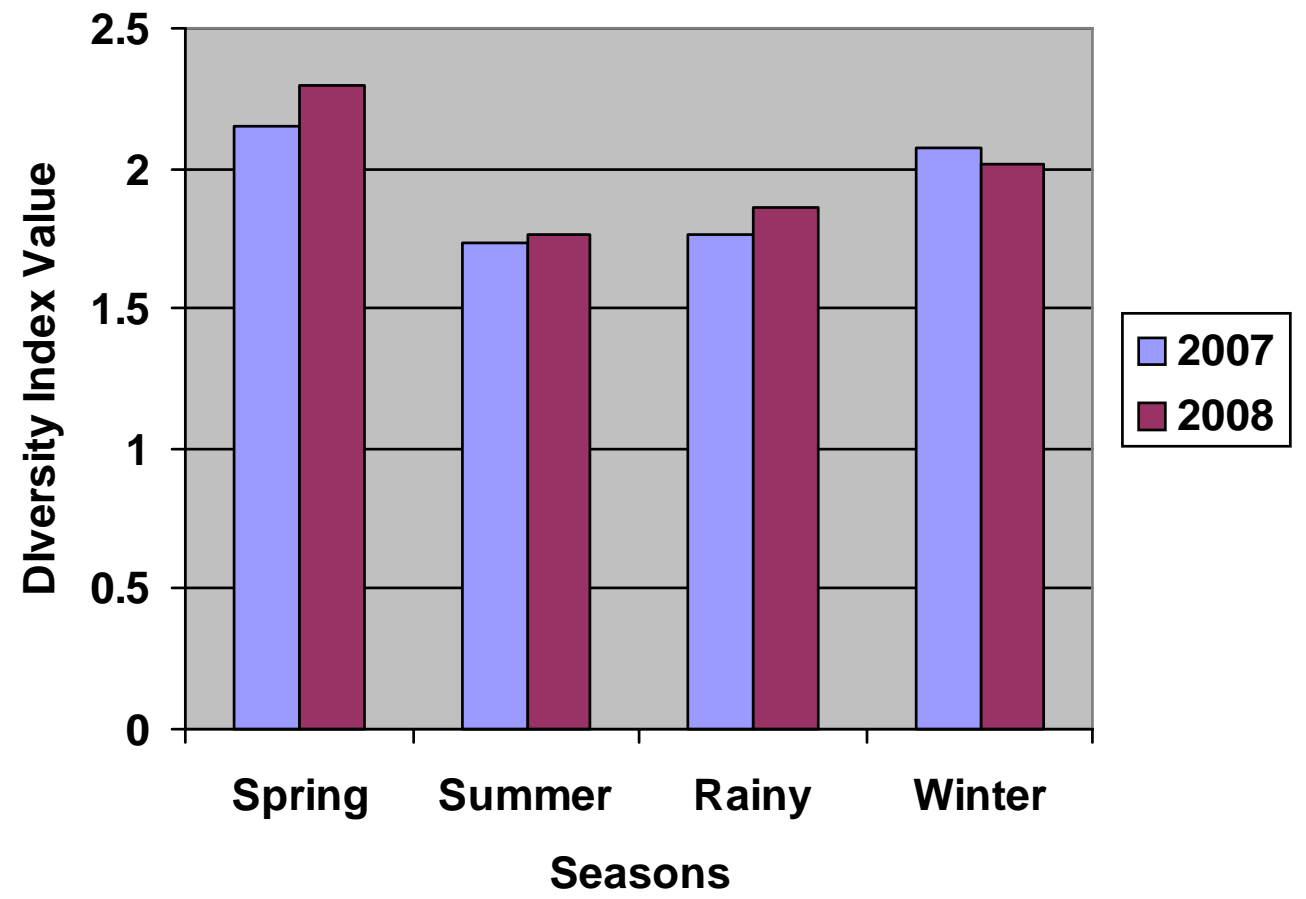

Figure 1. Seasonal variation in Species Diversity index calculated by Shannon-Weiner formula 


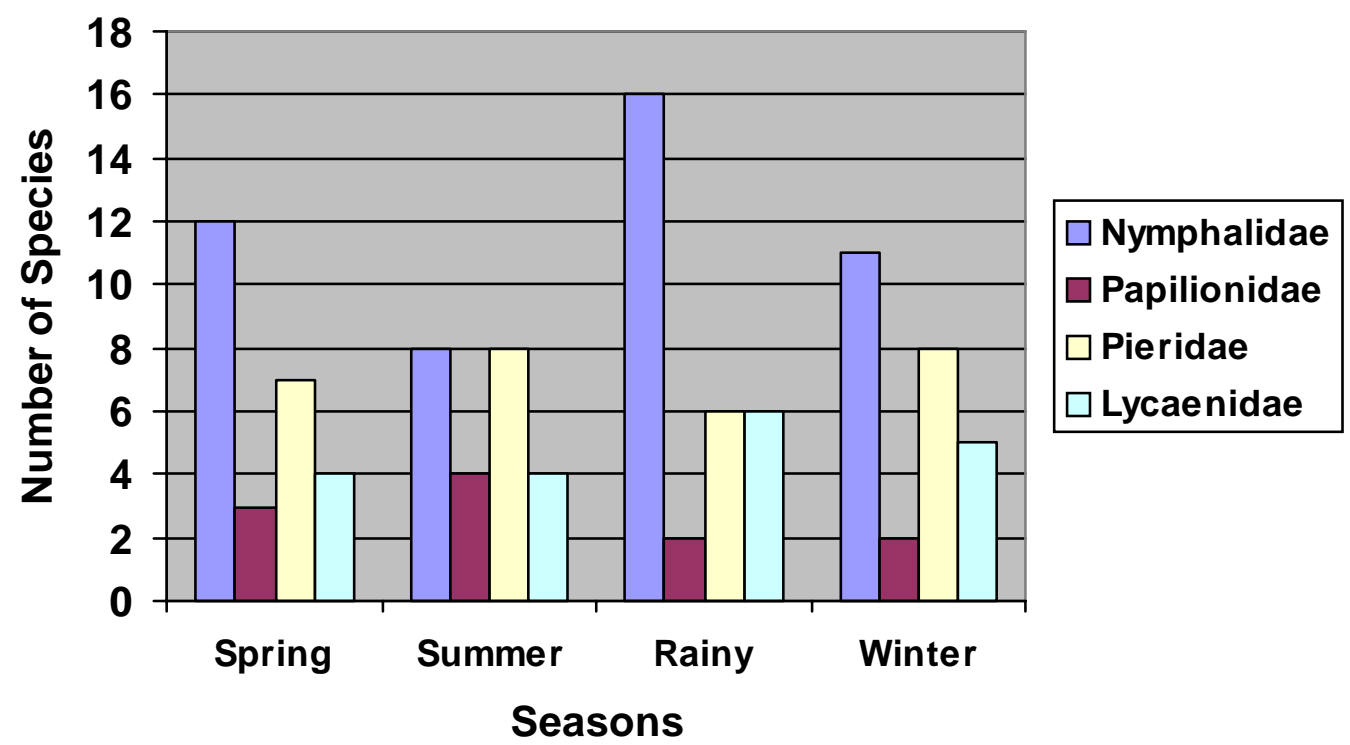

Figure 2. Diversity of Nymphalidae, Papilionidae, Pieridae and Lycaenidae across the 4 seasons (Spring, Summer, Rainy and Winter)

that the Dalma Wildlife Sanctuary has high Rhopaloceran species richness. It is not unlikely that a few butterfly species have escaped notice and will be added in the future: such species include Evening Browns (Melanitis), Grass Blues (Zizula, Zizina, Freyeria, etc.), the Peablue (Lampides boeticus), the Gram Blue (Euchrysops cnejus) etc.

Of the species recorded, most were common at suitable seasons and appeared to be well established.

Except for Euploea klugii (Moore) the butterflies recorded are typical of the lepidopteran community supported by Sal and Dry Deciduous forest over most of India, which is also present in the study area. In view of this, it is not felt that any special measures need to be adopted with reference to the conservation of lepidopteran diversity in the sanctuary.

\section{Conclusion}

Thirty-nine species of butterflies were recorded from the
Dalma Wildlife Sanctuary. The butterflies recorded are typical of Sal and Dry Deciduous forest present in the study area.

\section{References}

Ackery, P.R. (1975). A guide to the genera and species of Parnassiinae (Lepidoptera-Papilionidae). Bulletin of British Museum Natural History (Ent). 31(4): 73-105.

Brooks, M. \& C. Knight (1985). A Complete Pocket Guide to British Butterflies. Jonathan Cape Ltd., Italy.

Chandra, K., R.M. Sharma, A. Singh \& R. K. Singh (2007). A checklist of butterflies of Madhya Pradesh and Chhattisgarh States, India. Zoos' Print Journal 22(8): 2790-2798

Goodden, R. (1976) The Illustrated Encyclopedia of Butterflies and Moths. Worldwide Butterflies Ltd., London.

Kunte, K. (2000). Butterflies of Peninsular India (India- A Lifescape). University Press, Hyderabad. 